\title{
KEBIJAKAN POLSEK TIGADOLOK DALAM MEMBERANTAS PERJUDIAN DI KECAMATAN DOLOK PANRIBUAN
}

\author{
Oleh: \\ Mitra Bakara ${ }^{1)}$, Eka Magdalena ${ }^{2)}$, Nico Alfredho Sidabutar ${ }^{3)}$, \\ Theresia Simatupang ${ }^{4}$ \\ Universitas Prima Indonesia, Medan ${ }^{1,2,3,4)}$
}

\author{
E-Mail \\ $\underline{\text { mitrabakarayonzi@gmail.com }}^{\text {1) }}$, ekamagdalena97@gmail.com ${ }^{2)}$, \\ alfredhonico@gmail.com ${ }^{3)}$, simatupangtheresia99@gmail.com ${ }^{4}$ )
}

\begin{abstract}
Gambling is every game that bases the hope for a win generally depends only on luck. The expectation will increase because of intelligence and custom players. One area that many people commit the crime of gambling is Tigadolok police station area. The problem discussed in this journal is, how the role of the government in tackling was gambling in Tigadolok, what factors caused the people to commit the crime of gambling, how the policy of Tigadolok police station police forces tried to tackle gambling in Tigadolok. The method of research in writing this journal was empirical and normative legal research, which basically focused on research in the field and positive legal norms in the form of legislation relating to the cases in the study the mechanism of the police in combating gambling. The results showed that there was a gambling criminal case in the territory of the Tigadolok police station, with the number of cases from the year of 2013-2018 as many as 20 cases. The conclusions were that many efforts done in combating the disease pathology among them was through awareness about the laws governing the crime of gambling, and the main factor for the people committed the crime of gambling was the economic factors where people think that with gambling they could earn additional money for the family income, while police conduct the socialization of Bhayangkara Public Order and Safety Trustees (BABINKAMTIBMAS).
\end{abstract}

Key words: Gambling, custom players, combating gambling.

\section{PENDAHULUAN}

\section{A. Latar Belakang}

Negara Indonesia saat ini sedang melaksanakan pembangunan nasional yang dilaksanakan secara berkeseimbangan meliputi seluruh bidang kehidupan. Masyarakat Indonesia senantiasa mengalami perkembangan yang seiring dengan perkembangan dan kemajuan jaman, dengan demikian masyarakat memerlukan suatu keadaan ekonomi yang berkecukupan guna mempertahankan kelangsungan hidup.

Pola hidup yang cenderung konsumtif membuat setiap orang ingin mencapai apa yang dikehendaki dengan segala cara, sehingga berakibat timbulnya sebuah tindak pidana yang salah satunya adalah perjudian. 
Perjudian dapat menjadi penghambat pembangunan nasional yang beraspek material dan spiritual karena perjudian mendidik orang untuk mencari nafkah dengan tidak sewajarnya serta membentuk watak "pemalas", sedangkan pembangunan membutuhkan individu yang giat bekerja keras dan bermental kuat, hukum pidana sering kali digunakan untuk menyelesaikan masalah social dalam penanggulangan kejahatan khususnya masalah perjudian sebagai salah satu bentuk penyakit masyarakat.

Berdasarkan kasus tindak pidana perjudian yang terjadi di Tigadolok, maka penulis akan membahas

$\begin{array}{lr}\text { “KEBIJAKAN } & \text { POLSEK } \\ \text { TIGADOLOK } & \text { DALAM } \\ \text { MEMBERANTAS } & \text { PERJUDIAN DI } \\ \text { KECAMATAN } & \text { DOLOK } \\ \text { PANRIBUAN" } & \end{array}$

\section{B. Rumusan Masalah}

1. Bagaimana kebijakan pemerintah dalam menanggulangi perjudian di Tigadolok?

2. Faktor-faktor apa sajakah yang menyebabkan masyarakat melakukan perjudian?

3. Bagaimana upaya kepolisian dalam menanggulangi perjudian di tigadolok?

\section{Metode Penelitian}

Jenis penelitian dalam jurnal ini adalah yuridis empiris, yang dengan kata lain adalah jenis penelitian hukum sosiologis dan dapat disebut pula dengan penelitian lapangan,yaitu mengkaji ketentuan hukum yang berlaku serta apa yang terjadi dalam kenyataannya dalam masyarakat .Atau dengan kata lain yaitu suatu penelitian yang dilakukan terhadap keadaan sebenarnya atau keadaan nyata yang terjadi dimasyarakat dengan maksud untuk mengetahui dan menemukan fakta-fakta dan data yanhg dibutuhkan,setelah data yang dibutuhkan terkumpul kemudian menuju kepada identifikasi masalah yang pada akhirnya menuju pada penyelesaian masalah.

\section{D.Manfaat Penelitian}

\section{Manfaat Secara Teoritis}

Penulisan secara teoritis ini diharapkan dapat menambah wawasan dan pemahaman mengenai peran Pemerintah dan Kepolisian dalam menanggulangi judi di daerah Tigadolok dengan penyelidikan dan penyidikan dalam menindak kasus judi maupun upaya preventif dalam mencegah terjadinya perjudian.Serta menambah wawasan mengenai faktorfaktor yang menyebabkan terjadinya tindak pidana perjudian.

2.Manfaat Secara Praktis

Penelitian ini bermanfaat bagi masyarakat umum maupun bagi mahasiswa sebab dengan adanya penelitian ini maka dapat menambah pemahaman dan wawasan terkait dengan peran Pemerintah dan Kepolisian dalam menanggulangi judi di kawasan Tigadolok serta faktor penyebab terjadinya tindak pidana perjudian di Tigadolok.

\section{METODE PELAKSANAAN}

\section{Kerangka Teori}

Kerangka teoritis adalah konsepkonsep yang merupakan abstraksi dari hasil pemikiran atau kerangka acuan yang pada dasarnya bertujuan untuk mengadakan identifikasi dimensidimensi sosial yang dianggap relavan oleh peneliti. 
Kerangka teori yang digunakan agar penulis mudah dalam melakukan penelitian ini adalah sebagai berikut:

a. Teori penegak hukum

Penegak hukum pidana apabila dilihat dari suatu proses kebijakan maka penegak hukum pada hakikatnya merupakan penegakan kebijakan melalui beberapa tahap,yaitu:

1.Tahap formulasi,yaitu tahap penegak hukum oleh badan pembuat undang-undang,tahap ini disebut dengan tahap legislative.

2.Tahap aplikasi,yaitu tahap penerapan hukum pidana oleh aparat-aparat penegak hukum mulai dari kepolisian,sampai tahap pengadilan,tahap ini disebut dengan tahap kebijakan yudikatif.

3.Tahap eksekusi,yaitu tahap pelaksanaan hukum pidana secara kongkrit oleh aparat penegak hukum,tahap ini disebut dengan tahap kebijakan eksekutif atau administrative.

b. Teori yang mempengaruhi penegak hukum

Faktor penghambat upaya penegak hukum dapat menggunakan teori-teori mengenai faktor-faktor yang mempengaruhi penegak hukum adalah sebagai berikut:

a. Faktor hukum sendiri(perundangundangan)

Praktek penyelenggara hukum dilapangan seringkali terjadi kontradiksi antara hukum dan keadilan,hal ini dikarenakan konsepsi keadilan merupakan rumusan yang bersifat abstrak,sedangkan kepastian keadilan merupakan prosedur yang telah ditentukan secara normatif.Oleh karena itu,suatu kebijakan atau tindakan yang tidak melanggar atau bertentangan dengan hukum dapat dibenarkan.

b. Faktor penegak hukum Penegak hukum adalah mereka yang secara langsung dan tidak secara langsung berkecimpung dibidang penegak hukum yang tidak hanya mencakup law enforcement, akan tetapi juga peace maintenance.

b. Faktor sarana atau fasilitas

Sarana atau fasilitas mempunyai peranan yang sangat penting didalam penegak hukum. Tanpa adanya sarana atau fasilitas tersebut,maka tidak mungkin penegak hukum akan berlangsung dengan lancar dan menyerasikan peranan yang seharusnya dengan peran yang aktual.

d. Faktor masyarakat

Penegak hukum berasal dari masyarakat dan bertujuan untuk mencapai kedamaian didalam masyarakat.Oleh karena itu,masyarakat dapat mempengaruhi penegak hukum dimana peraturan hukum berlaku atau diterapkan.Bagian terpenting dari masyarakat yang menentukan penegak hukum adalah kesadaran hukum masyarakat

e. Faktor kebudayaan

Budaya atau adat menjadi salah satu penghalang yang utama karena ikatan atau kekerabatan dari marga saling berhubungan sehingga menimbulkan presepsipresepsi tertentu bagi para pegak hukum. 
f. Faktor kebiasaan dalam acara adat Dalam acara adat terkhususnya dalam adat batak seringkali masyarakat melakukan judi sebagai sebuah permainan untuk saling mengakrabkan satu sama lainnya.

\section{Kerangka Konsepsi}

Konseptual adalah kerangka yang menggambarkan suatu konsep-konsep khusus yang merupakan kumpulan dalam arti yang berkaitan dengan istilah yang ingin atau yang akan diteliti.

Agar tidak terjadi kesalahan kesalahpahaman terhadap pokok permasalahan dan pembahasan skripsi ini,maka dibawah ini ada beberapa konsep yang bertujuan untuk menjelaskan istilah-istilah yang dapat dijadikan pegangan dalam memahami skripsi ini.

a. Upaya adalah suatu metode kepolisian atau penegak hukum.

b. Penanggulangan adalah pencegahan tindak pidana perjudian.

Peranan Pemerintah Dalam Menanggulangi Perjudian Di Tigadolok

\section{A. Perjudian}

\section{Pengertian Perjudian}

Perjudian merupakan permainan yang terdiri dari beberapa orang dimana para pemain bertaruh dan berlomba untuk menjadi pemenang, pemain yang kalah harus memberikan taruhannya kepada pemenang. Berbagai cara dilakukan dalam penanganan perjudian yang saat ini tetap hidup dalam masyarakat.Meski pada hakekatnya perjudian merupakan perbuatan yang bertentangan dengan kenorma agama, kesusilaan, maupun hukum, namun perjudian masih menunjukkan eksistensinya, dulu hanya terjadi dikalangan orang dewasa pria.Sekarang sudah menjalar keberbagai elemen masyarakat anak-anak dan remaja yang tidak lagi memandang baik pria maupun wanita Perjudian membahayakan bagi penghidupan dan kehidupan masyarakat, bangsa dan Negara. Meski demikian berbagai perjudian tetap berkembang seiring dengan berkembangnya peradapan manusia.Macam dan bentuk perjudian saat ini sudah merebak kedalam kehi dupan masyarakat sehari-hari. Mengingat masalah perjudian sudah menjadi penyakit akut masyarakat,maka perlu upaya penanggulangan yang sungguh-sungguh dan sistematis.

\section{Unsur-Unsur Tindak Pidana Perjudian}

Dari pemaparan diatas mengenai perjudian,maka ada tiga unsur yang harus terpenuhi agar suatu perbuatan dapat dikatakan perjudian,ketriga unsure tersebut adalah:
a. Permainan/Perlombaan

Permainan yang dilakukan biasanya berbentuk permainan atau perlombaan. Perbuatan ini dilakukan semata-mata untuk bersenang-senang atau kesibukan untuk mengisi waktu senggang guna menghibur hati.

\section{b.Untung-Untungan}

Untuk memenangkan perlombaan atau permainan, lebih banyak digantungkan pada unsur spekulatif/kebetulan atau untunguntungan, atau faktor kemenangan yang diperoleh dikarenakan kebiasaan atau kepintaran pemain yang sudah sangat terbiasa atau kepintaran pemaian yang sudah sangat terbiasa atau tertarik.

\section{c. Ada Taruhan}

Dalam permainan atau perlombaan ini ada taruhan yang dipasang oleh para pihak pemain atau bandar, baik dalam 
bentuk uang atau harta benda lainnya, bahkan istri sekali pun dijadikan taruhan. Akibat adanya taruhan tersebut,maka tentu ada saja para pihak yang diuntungkan dan ada pihak yang dirugikan. Unsur ini merupakan unsur yang paling utama untuk menetukan apakah sebuah perbuatan dapat disebut perjudian atau bukan.

\section{Jenis Tindak Pidana Perjudian}
a. Perjudian Kasino
b. Permainan atas meja
c. Permainan elektronik, jenis- jenisnya yaitu: Pachinko, Mesin slot, Poker,video, Bingo, Keno

\section{B. Kebijakan Pemerintah Tigadolok}

1. Melalui Pendidikan

Pemerintah menanggulagi

perjudian melalui pendidikan. Melalui program wajib belajar, Pemerintah berharap agar penyakit patalogi khususnya judi yang berkembang di masyarakat tidak menjadi penyakit sosial yang sudah membudaya dikalangan masyarakat. Melalui dunia pendidikan seorang individu akan belajar nilai,norma dan aturan yang berlaku.

\section{Melalui Sosialisasi}

Pemerintah Kecamatan Dolok Panribuan selalu melakukan pendekatan atau sosialisasi dalam penyampaian nilai, norma dan peraturan yang mengatur tentang perjudian secara berulang-ulang dengan harapan agar lewat penyampaian ini dengan cara yang ramah masyarakat dapat dengan mudah memahami sanksi jika melakukan tindak pidana judi sehingga melalui ini penyampain ini dapat mengurangi angka tindak pidana perjudian di daerah Tigadolok.

3. Melalui Rehabilitasi Patologi $\begin{array}{crr}\text { Pihak } & \begin{array}{r}\text { Pemerintah } \\ \text { pengendalian }\end{array} & \text { atau } \\ \text { melakukan } & \text { ang }\end{array}$ penanggulangan penyakit sosial ini melalui upaya pencengahan dan rehabilitasi Patologi Sosial tersebut melalui penertipan anggota masyarakatnya yang menyimpang, melanggar atau,membangkak terhadap nilai,aturan dan norma.Pengendalian ini dilakukan untuk mencegah munculnya penyimpangan sosial dan penyakit.Pengendalian sosial dilakakukan agar masyarakat mau mematuhui aturan dan norma yang berlaku.Disamping itu,pengendalian ini agar terwujud keserasian masyarakat,tercipta ketertipan dalam kehidupan,memperingatkan para pelaku untuk tidak melakukan penyimpangan atau tindaakan berjudi yang bertentangan dengan nilai,norma dan aturan hukum yang berlaku dikalangan masyarakat ataupun Negara.

4.Melalui Agama

Pemerintah Tigadolok juga tidak lupa meminta bantuan kepada setiap pengurus agama sesuai dengan kepercayaan masyarakatnya untuk mengingatkan masyarakat agar tidak melakukan tindak pidana perjudian ini,karena orang yang memiliki agama akan memahami bahwa melanggar nilai,norma atau aturan disamping hukum dunia ini juga ada dunia akhirat.Dengan peran agama ini maka setiap invidu akan terkendali setiap perbuatannya untuk tidak melakukan atau melanggar nilai,norma maupun aturan yang berlaku tersebut.

\section{HASIL DAN PEMBAHASAN}

Faktor Yang Menyebabkan Masyarakat Melakukan Perjudian

A. Faktor Ekonomi

Sosial 
Perjudian digemari oleh seluruh golongan masyarakat, terutama oleh masyarakat berpenghasilan rendah. Pada umumnya orang melakukan permainan judi didasarkan oleh hobbi atau hiburan saja. Disamping itu juga didorong oleh adanya keinginan keras untuk memperoleh keuntungan yang besar atau berlipat ganda, dengan cara taruhan yang kemenangannya tergantung pada untung-untungan dan juga karena kemahiran bermain.

\section{B. Faktor Kecanduan}

Dimana seseorang sering memiliki kesempatan menang yang sehingga menyebabkan seseorang tersebut ingin melakukan perjudian tersebut secara berulang-ulang.

\section{Faktor Hukum}

Data hasil penelitian menunjukkan bahwa tidak adanya sosialisasi atau penyuluhan mengenai bahaya judi dan dan hukuman yang tepat bagi masyarakat jika didapat berjudi togel, sehingga masyatarakat tidak segan lagi berkumpul dan melakukan permainan judi. Selain itu karena sering melihat bahwa aparat Kepolisian juga ikut melakukan permainan judi masyarakat seakan-akan tidak takut lagi dan secara terang terangan berjudi. Hal ini lah yang menyebabkan semakin maraknya judi dikalangan masayarakat akibat lemahnya hukum dalam menangani masalah perjudian.

\section{Faktor Tingkat Pendidikan}

Rendahnya pendidikan
menyebabkan seseorang berpikir
pragmatis dan sederhana yakni berpikir
kalau semakin besar jumlah taruhan
maka akan semakin besar keuntungan
dari hasil kemenangan, sementara
mereka tidak membandingkan berapa peluang menang dan kalah. Semuanya berpikir pada kemenangan dan kemenangan saja.

\section{F. Faktor Lingkungan}

Lingkungan sosial memiliki pengaruh yang sangat besar terhadap keinginan untuk bermain judi. Berita mengenai para penjudi yang berhasil menang memberikan kesan kepada para calon penjudi kemenangan dalam perjudian adalah suatu yang biasa, mudah dan dapat terjadi pada siapa saja (padahal kenyataan menang adalah sangatlah kecil). Dengan demikian mungkin judi sudah merupakan penyakit sosial yang usianya sebaya dengan kelahiran manusia dan tetap saja ada mengisi kebutuhan manusia.

\section{G.Keingintahuan}

Faktor belajar atau keingintahuan terhadap hal-hal yang menjadi topik hangat pembicaraan dalam masyarakat juga mendorong seseorang untuk melakukan judi.pelaku beranggapan bahwa siapapun dapat menang termasuk dirinya sehingga muncul rasa penasaran untuk melakukanya berulangkali.

\section{H. Persepsi Tentang Kemenangan}

Harapan peluang dalam meraih kemenangan cendrung dianggap keliru dengan kemungkinan untuk menang sehingga muncul masalah baru karena presepsi yang dimaksud tidak sesuai dan berjalan mulus.pelaku judi sering menganggap bahwa kemenangan tau keberhasilan dalam permainan judi adalah keterampilan yang dimiliki oleh dirinya. 
Upaya Kepolisian Dalam

Menanggulangi Perjudian Di

Tigadolok

A. Upaya Kepolisian Dalam

Menanggulangi Tindak Pidana

Perjudian di Kecamatan Dolok

Panribuan

Adapun upaya yang dilakukan Polsek

Tiga Dolok, kecamatan Dolok Panribuan dalam menanggulangi tindak pidan perjudian adalah sebagai berikut :

1. Upaya Pre-Emtif

Merupakan upaya yang

dilakukan oleh pihak kepolisian untuk mencegah terjadinya tindak pidana. Usaha-usaha tersebut dilakukan dengan cara menerapkan nilai-nilai dan normanorma yang baik kepada masyarakat,upaya ini tediri dari :

a. Bhayangkara Pembina, Keamanan dan Ketertiban Masyarakat (Bhabinkamtibmas)

Salah satu upaya pencegahan yang dilakukan kepolisian dengan menugaskan beberapa polisi untuk langsung berinteraksi dengan masyarakat. Sebagaimana diatur dalam pasal 27 Peraturan kapolri Nomor 3 Tahun 2015 antara lain sebagai berikut:

Tugas Pokok Bhabinkamtibmas adalah melakukan pembinaan masyarakat,deteksi dini dan mediasi/negosiasi agar tercipta kondisi kondusif disetiap desa/kelurahan. Dalam melaksanakan tugas pokok tersebut, bhabinkamtibmas melakukan kegiatan sebagai berikut :

1. Kunjungan dari rumah kerumah pada wilayah penugasannya

2. Melakukan dan membantu pemecahan masalah
3 Melakukan pengaturan dan pengamanan kegiatan masyarakat

4. Menerima informasi tentang terjadinya tindak pidana

5. Memberikan perlindungan sementara kepada orang yang tersesat,korban kejahatan dan pelanggaran

6. Ikut serta dalam memberikan bantuan kepada korban bencana alam dan wabah penyakit

7. Memberikan bimbingan dan petunjuk kepada masyarakat atau komunitas berkaitan dengan permasalahan kamtibmas dan pelayanan Polri.

b. Melakukan penyuluhan Hukum dikantor desa/tokoh masyakarat

\section{Upaya Preventif}

Upaya ini masih dalam kategori mencegah sebelum terjadinya tindak pidana perjudian tersebut. Dalam upaya ini Polsek Tigadolok melakukan kegiatan dimana kegiatan ini dilakukan untuk menghilangkan kesempatan masyarakat melakukan perjudian. Upaya itu sendiri berupa patroli/pengawasan secara rutin dan berkelanjutan, kegiatan ini dilakukan oleh pihak Polsek Tigadolok di tempattempat yang rawan dilakukan nya perjudian seperti warung-warung dan rumah yang dicurigai sebagai tempat dilakukannya perjudian. Dengan melakukan kegitan seperti ini masyarakat menjadi takut untuk melakukan kegiatan perjudian. 


\section{Upaya Represif}

Upaya represif atau upaya penal yang dilakukan oleh polisi, khususnya Polsek Tigadolok adalah dengan menagkap dan menerpakan pasal 303 dan/atau pasal 303 bis KUHP kepada pelaku-pelakunya. Tugas polisi dalam hal ini dimulai dengan adanya laporan dari masyarakat setempat bahwa telah terjadi suatu peristiwa yang diduga kegiatan perjudian. Setelah mendengar laporan tersebut pihak polisi melakukan penyelidikan.Dalam melakukan penyelidikan, polisi segera terjun kelokasi kejadian untuk mencari tahu apa benar telah terjadi tindak pidana perjudian sesuai dengan laporan masyarakat. Apabila benar telah terjadi perjudian selanjutnya polisi akan melakukan penangkapan terhadap orang-orang yang terlibat dalam kegiatan perjudian dan mengumpulkan barang bukti dan saksi. Dalam hal ini pelaku perjudian tertangkap tangan. Yang dimaksud dengan tertangkap tangan sebagaimana diatur dalam pasal 1 angka 19 KUHAP adalah:

1. Tertangkapnya seseorang pada waktu sedang melakukan tindak pidana atau dengan segerra sesudah beberapa saat tindak pidana itu dilakukan

2. Tertangkapnya seseorang apabila sesaat kemudian ditemukan benda yang diduga keras telah dipergunakan untuk melakukan tindak pidana itu yang menunjukan bahwa ia adalah pelakunya atau turut melakukan atau membantu melakukan tindak pidana itu segera setelah tersangka ditangkap dan barang bukti beserta saksi telah dikumpulkan, tesangka dan barang bukti yang ada kemudian diserahkan kepada penyidik guna kepentingan penyidikan.

\section{KESIMPULAN DAN SARAN A.KESIMPULAN}

Perjudian merupakan bentuk penyimpangan sosial yang ada di daerah Kecamatan Dolok Panribuan.Judi didaerah Tigadolok memang tidak mengenal status sosialnya,dan terdapat berbagai macam faktor yang mendorong pelaku judi untuk selalu melakukan judi anatara lain adalah : faktor ekonomi yang dimana pelaku perjudian berharap dengan berjudi mereka mendapatkan keberuntungan sehingga mendapatkan uang untuk mengurangi beban kebutuhan pokok,faktor situsional yang dimana tekanan dari temanteman,kelompok atau lingkungan untuk ikut berpartisipasi dalam perjudian dan metode pemasaran yang dilakukan oleh pengelola perjudian,tekanan kelompok membuat calon penjudi merasa tidak enak jika menolak,faktor keingintahuan atau belajar ini mendorong seseorang untuk melakukan judi,pelaku beranggapan bahwa siapapun dapat menang termasuk dirinya sehingga muncul rasa penasaran untuk melakukannya berurangkali, faktor presepsi peluang kemenangan seringkali menjadi harapan untuk meraih kemenangan sehingga muncul masalah baru karena presepsi yang dimaksud tidak sesuai dan berjalan mulus,pelaku judi sering beranggapan bahwa kemenangan atau keberhasilan dalam permainan judi adalah keterampila yang dimiliki oleh dirinya.

Dalam menangulangi penyakit patologi tersebut pemerintah daerah melakukan penangulangan dimana diantaranya adalah sebagai berikut: 
melalui pihak Kepolisian yang merupakan salah satu organ atau lembaga Pemerintahan yang berperan menanggulangi perjudian,melalui pendidikan dimana melalui program wajib belajar Pemerintah berharap penyakit patalogi semakin berkurang dan tidak menjadi penyakit sosial yang membudaya lagi dikalangan masyarakat, penanggulangan melalui sosialisasi yang dilakukan Pemerintah Tigadolok dimana penanggulangan ini melalui tahap pedekatan dalam penyampaian nilai,norma,dan peraturan yang mengatur tentang perjudian secara berulang-ulang dengan harapan agar lewat penyampaian ini dengan cara yang ramah masyarakat dapat dengan mudah memahami sanksi jika melakukan tindak pidana judi sehingga mengurangi angka tindak pidana perjudian didaerah Tigadolok.

\section{B. Saran}

\section{Bagi Pelaku Perjudian}

a. Perjudian tidak bisa diandalkan sebagai mata pencaharian uang yang menguntungkan, dengan bekerja damn kreatifitaslah kita dapat mencarai uang yang tidak menyimpang dari ajaran agama dan hukum yang berlaku di Negara kita.

c. Perjudian berdampak negatif bagi para pelaku misalnya bertentangan dengan pihak keluarga, ekonomi, maupun kesehatan. Dengan demikian janganlah melakukan perjudian walaupun hanya hiburan semata.

\section{Bagi Masyarakat}

Lingkungan yang sehat adalah lingkungan yang jauh dari konflik kesenjangan ekonomi, nyaman dan tentram. Menjaga satu sama lain adalah kewajiban dari setiap warga masyarakat untuk mewujudkan hal tersebut, termasuk dalam memberikan nasihat dan pengarahan bagi para pelaku perjudian untuk menyadarkan mereka agar menjauhi kegiatan perjudian karena kegiatan itu sangat merugikan dirinya sendiri ataupun bagi generasi muda masa depan.

\section{Bagi Pihak Kepolisian dan} Pemerintah Daerah

Meningkatkan pengawasan karena dengan begitu warga akan trakut melakukan kegiatan yang melanggar hukum. Pelaku perjudian yang tertangkap untuk diproses sesuai dengan undangundang yang berlaku di Indonesia. Bagi Pemerintah Daerah agar meningkatkan sosialisasi dalam masyarakat agar tercipta kehidupan yang aman,nyaman,dan tentram. Jangan ikut serta dalam melakukan kegiatan patalogi seperti judi, karena anda adalah panutan bagi masyarakat. Berilah contoh yang baik bagi masyarakat anda karena perkataan dan perbuatan anda jadi panutan bagi masyarakat.

\section{Bagi Keluarga Penjudi}

Keluarga adalah kelompok sosial yang terkecil dari masyarakat dan kerluarga adalah pembentuk karakter pribadi seseorang,yang dimana berfungsi mengontrol masing-masing individu atau anggota keluarga.Awasi dan berikan contoh yang baik bagi anggota keluarga anda dan 
bangun kebiasaan keluarga yang positif,apalagi dalam membangun kepribadian anak haruslah dengan pantauan dan binbingan yang ekstra.

\section{DAFTAR PUSTAKA}

Arisanti, Heny Septriana. Upaya Polri Dalam Mengungkap Tindak Pidana Perjudian di Kalangan Masyarakat Kalangan Berpenghasilan Rendah (Studi di Polres Tenggarek). Skripsi. Universitas Brawijaya. Malang.
Haryanto. 2003. Indonesia Negara Judi. Yayasana Khasana Insan Mandiri. Jakarta.

Kartini Kartono. 1981. Patologi Sosial Jilid I. Rajawali, Jakarta,.C.S.T

Kansil dan Christine S.T. Kansil. 2002. Hukum dan Tata Negara Republik Indonesia Cetakan Ketiga, Rineka Cipta. Jakarta.

So Sudarsono. 2008. Kenakalan remaja, Bhineka Cipta. Jakarta,

Serjono Soekanto.1986. Pengantar Penelitian Hukum. UI Press. Jakarta 